\title{
Observational description of the atmospheric and oceanic boundary layers over the Atlantic Ocean
}

\author{
Marcelo Dourado ${ }^{1}$ \& Amauri Pereira de Oliveira ${ }^{2}$ \\ ${ }^{1}$ Universidade Federal do Rio de Janeiro \\ Departamento de Meteorologia/IGEO \\ (Av. Brigadeiro Trompwski s/n, 21945-970, Rio de Janeiro, RJ, Brazil) \\ e-mail: dourado@acd.ufrj.br \\ ${ }^{2}$ Instituto de Astronomia, Geofísica e Ciências Atmosféricas da Universidade de São Paulo \\ Grupo de Micrometeorologia, Departamento de Ciências Atmosféricas \\ (Rua do Matão, 1226, 05508-900, São Paulo, SP, Brazil) \\ e-mail: apdolive@usp.br
}

- Abstract: Time evolution of atmospheric and oceanic boundary layers are described for an upwelling region in the Atlantic Ocean located in Cabo Frio, Brazil $\left(23^{\circ} 00^{\prime} \mathrm{S}, 42^{\circ} 08^{\prime} \mathrm{W}\right)$. The observations were obtained during a field campaign carried out by the "Instituto de Estudos do Mar Almirante Paulo Moreira", on board of the oceanographic ship Antares of the Brazilian Navy, between July 7 and 10 of 1992. The analysis shown here was based on 19 simultaneous vertical soundings of atmosphere and ocean, carried out consecutively every 4 hours. The period of observation was characterized by a passage of a cold front that penetrated in Cabo Frio on July 6. During the cold front passage the vertical extension of atmospheric (and oceanic) mixed layer varied from $200 \mathrm{~m}$ (and $13 \mathrm{~m}$ ) to $1000 \mathrm{~m}$ (and 59 $\mathrm{m}$ ). These changes occurred in the first day of observation and were followed by an increase of $1.2^{\circ} \mathrm{C}$ in the oceanic mixed layer temperature and by a decrease of $6 \mathrm{~K}$ and $6 \mathrm{~g} / \mathrm{kg}$ in the virtual potential temperature and specific humidity of the atmospheric mixed layer. The short time scale variations in the ocean can be explained in terms of the substitution of cold upwelling water by warm downwelling water regime, as the surface winds shift from pre-frontal NE to post-frontal SSW during the cold front passage in Cabo Frio. The large vertical extent of the atmospheric mixed layer can be explained in terms of an intensification of the thermal mixing induced by the warming of the oceanic upper layers combined with the cooling of the lower atmospheric layers during the cold front passage. An intensification of the mechanical mixing, observed during the cold front passage, may also be contributing to the observed variations in the vertical extent of both layers.

- Resumo: A evolução temporal das camadas limites atmosféricas e oceânicas são descritas para a região de ressurgência do Oceano Atlântico localizada em Cabo Frio. As observações foram obtidas durante a campanha de medidas realizada pelo Instituto de Estudos do Mar Almirante Paulo Moreira, a bordo do Navio Oceanográfico Antares da Marinha Brasileira, entre 7 e 10 de julho de 1992. As análises mostradas aqui estão baseadas em 19 sondagens verticais simultâneas da atmosfera e do oceano. Estas sondagens foram feitas a cada 4 horas e durante a passagem de uma frente fria, que chegou em Cabo Frio no dia 6 de julho. Durante a passagem da frente fria a extensão vertical da camada de mistura atmosférica (e oceânica) variou de $200 \mathrm{~m}(13 \mathrm{~m})$ a $1000 \mathrm{~m}(59 \mathrm{~m})$. Estas modificações ocorreram no primeiro dia de observação e foram acompanhadas por um aumento de $1.2^{\circ} \mathrm{C}$ na temperatura da camada de mistura oceânica e por uma diminuição de $6 \mathrm{~K}$ na temperatura potencial virtual e de $6 \mathrm{~g} / \mathrm{kg}$ na umidade específica da camada de mistura atmosférica. Estas variações do oceano em escala de tempo curta podem ser explicadas em termos da substituição do fluxo ascendente, de água relativamente mais fria, da ressurgência pelo fluxo descendente, de água relativamente mais quente, a medida que os ventos de superfície variam de NE (pré-frontal) para SSW (pós-frontal) durante a passagem da frente fria em Cabo Frio. As variações observadas na altura da camada de mistura atmosférica são consistentes com a intensificação da mistura térmica induzida pelo aquecimento da superfície do oceano combinado com o resfriamento da camada mistura atmosférica durante passagem da frente fria. A intensificação da mistura mecânica, observada durante a passagem da frente fria em Cabo Frio, pode também ter contribuído para as variações observadas em ambas camadas.

- Descriptors: Atmospheric boundary layer; Oceanic boundary layer; Upwelling; Cabo Frio, Cold front.

- Descritores: Camada limite atmosférica; Camada limite oceânica; Ressurgência, Cabo Frio; Frente fria. 


\section{Introduction}

Processes in the air-sea interface are directly affected by the presence of boundary layers in the ocean and atmosphere, which in turn are modulated by heat, moisture, momentum and trace constituent exchange across the air-sea interface. In the interface the exchange is performed by molecular transport. Away from the surface $(>1 \mathrm{~mm})$ heat, moisture, momentum and trace constituents are mixed by turbulent processes. The atmospheric and oceanic boundary layers (ABL and $\mathrm{OBL}$ ) are also directly affected by transport of energy across the inversion and the pycnocline.

Several observational campaigns have tried to characterize the structure of these boundary layers over tropical and subtropical open sea. Geernaert (1990) has outlined much of the experimental basis for air-sea interaction research tracing its history from the 1950s. The early studies focused in the wind stresses and were conducted over small bodies of water. In the late $1950 \mathrm{~s}$, open ocean measurements of turbulent fluxes became more frequent. The Barbados Oceanic and Meteorological Experiment (BOMEX), carried out in 1969 (Holland \& Rasmusson, 1973) and Atlantic Trade-Wind Experiment (ATEX) 1969 (Augstein et al., 1973) concentrated on the observational characterization of structure of the ABL during convective conditions. In 1974, the Tropical Atlantic Experiment (GATE) in the Global Atmospheric Research Program (GARP), focused on the subcloud and cloud layer in conditions of deep convection. In this experiment emphasis was given to the $\mathrm{ABL}$ evolution under disturbed conditions (Houze, 1977; Zipser, 1977; Fitzjarrald \& Garstang, 1981).

Measurements made by airplane have been useful to study the turbulent structure of subcloud layer (LeMone \& Pennell, 1976; Nicholls \& LeMone, 1980) and the interaction between subcloud and cloud layers (Kloesel \& Albrecht, 1989). Radiosondes data have been used to study the structure of the atmosphere on tropical Pacific Ocean (Reed \& Recker, 1971; Yanai et al., 1973, Kloesel \& Albrecht, 1989). Dropwindsondes launched on the Tropical Pacific Ocean during the First GARP Global Experiment (FGGE), between January and February 1979, were used to study the characteristics of the $\mathrm{ABL}$ in the Central Pacific (Firestone \& Albrecht, 1986; Betts and Albrecht, 1987). These observations are of particular interest because they covered large portions of the tropical Pacific Ocean (Klosel \& Albrecht, 1989). TOGA COARE (Webster \& Lukas, 1992) was focused on the role of large atmospheric convective systems (Westerly Wind Bursts) on triggering El-Niño events. The Surface of the Ocean, Fluxes and Interactions and Atlantic Stratocumulus Transition Experiment (SOFIA/ASTEX) was devoted to investigate the air-sea interactions and cloud development in the Azores region of the Atlantic Ocean (Dupuis et al., 1993; Albrecht et al., 1994). The World Ocean Circulation Experiment (WOCE), as TOGA COARE, has highlighted the importance of process studies for a satisfactory understanding of global climate and ocean general circulation problems (Taylor, 1989). These experiments represent most of the available information on the $\mathrm{ABL}$ in the tropical and subtropical open sea regions.

Friehe et al. (1991) investigated the effect of the sea surface temperature fronts on atmospheric boundary layer structure during the Frontal Air Sea Interaction Experiment (FASINEX). They showed that warm air blowing over cold water leads to a stable, shallow boundary layer, while cold air blowing over warm water leads to an unstable, growing boundary layer. Austin \& Lentz (1999) have described the effect of synoptic scale weather systems on temporal and spatial variation of the energy, mass and momentum exchange between atmosphere and ocean. They used surface fluxes estimated from observations carried out in the coast of North Caroline and North of Cape Hatteras, during August and October through November of 1994. Austin (1999) has used the same data set to investigate the relationship between atmospheric heat sources and variability in the heat content of the North Caroline inner shelf. Even though, these later studies quantified the role played by synoptic scale disturbances on coastal areas of the Atlantic, their results can not be easily extrapolated to subtropical or tropical regions.

One attempt to investigate the interaction between atmosphere and ocean in the Atlantic Ocean was carried out in the coastal region of Cabo Frio in July 1992. This area is particularly important due to the presence of upwelling of cold waters (Stech, \& Lorenzzetti, 1992; Torres, 1995). During a period of one week the "Instituto de Estudos do Mar Almirante Paulo Moreira (IEAPM)" carried out a campaign of intensive measurements of the thermal structure in the lower layers of atmosphere and upper layers of the ocean (Dourado, 1994). This campaign was sponsored by the Brazilian Navy as part of SISPEM program.

In Cabo Frio, the effect of upwelling up on the OBL has been documented (Stech \& Lorenzzetti, 1992, Torres, 1995). However, observations of the upwelling impact on the $\mathrm{ABL}$ and changes caused by synoptic scale disturbances, like cold front, is not available in the literature. Fortunately, during the experiment carried in July of 1992 by IEAPM, there was a cold front passage by Cabo Frio area, modifying significantly both atmosphere and ocean. The main objective of this paper is to describe the time evolution of the atmospheric and oceanic boundary layers observed during this experiment, focusing on the effects caused by the cold front 
passage in Cabo Frio. In this paper a description of the campaign, instrumentation and method used to estimate the properties of these two boundary layers are shown in the section: Description of measurements. The results are discussed in the section: Discussion and summarized in the Conclusion.

\section{Description of measurements}

Simultaneous probing of the atmosphere and ocean were carried out between July 7 and 10, 1992, on board of the Oceanographic Ship Antares of the Brazilian Navy ("Diretoria de Hidrografia e Navegação"). The ship was anchored in $23^{\circ} 00^{\prime} \mathrm{S}$ and $42^{\circ} 08^{\prime} \mathrm{W}$, a region of the Atlantic Ocean located about 4 nautical miles far from the continent, where the depth is $60 \mathrm{~m}$ (Fig. 1). This observational campaign was conducted in the Cabo Frio coastal area, where the upwelling cold water is the dominant feature. In July, this area is characterized by mild cold air temperature associated to the penetration of cold fronts from South. For undisturbed conditions, the NE Trade Winds is the dominant feature at low levels that during winter months favors the upwelling regime in Cabo Frio region.

\section{Instruments}

Vertical structure of the atmosphere was obtained from radiosondes (AIRSONDE) system coupled to a data acquisition system (ADAS) both manufactured by A.I.R. INC. The AIRSONDE has an accuracy of: $0.5^{\circ} \mathrm{C}$ (temperature), $5 \%$ (relative humidity) and $1 \mathrm{hPa}$ (pressure), in the following range: $-40^{\circ} \mathrm{C}$ and $+40^{\circ} \mathrm{C}$ (temperature); $10 \%$ and $100 \%$ (relative humidity); 5 and $1050 \mathrm{hPa}$ (pressure). During ascension the AIRSONDE sampled one value of temperature, pressure and humidity every $10 \mathrm{~s}$. Each probing was set up with an ascension rate of 1 $\mathrm{m} / \mathrm{s}$ resulting in a vertical resolution of $10 \mathrm{~m}$. The ascension rate was controlled by filling all balloons with a ballast of $180 \mathrm{gr}$. In the period of observation, one sounding was carried out every 4 hour, totaling twenty-one soundings. Simultaneous vertical profiles of temperature in the ocean were obtained using MK9 system manufactured by SIPPICAN. This system is composed by a disposable sounding lead launching pad and an analogical-digital converter. In the oceanic soundings, temperature measurements were carried out with sampling rate of $10 \mathrm{~Hz}$ and vertical speed of $6.5 \mathrm{~m} / \mathrm{s}$. They were also obtained every 4 hours, totaling nineteen temperature vertical profiles. Technical problems caused the lost of two oceanic soundings. On board global solar radiation

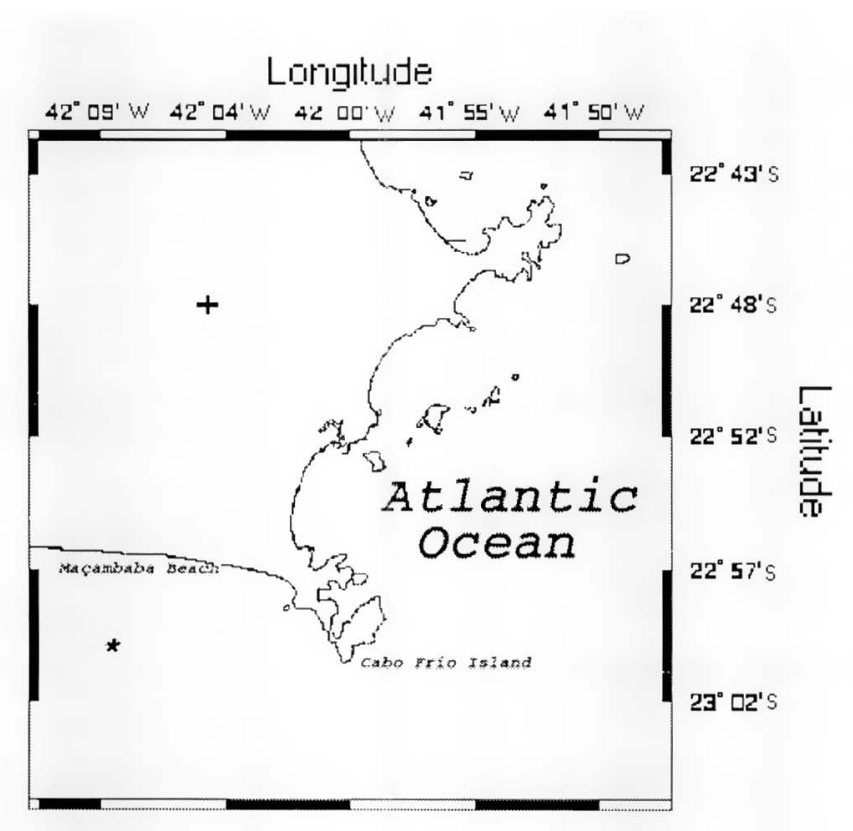

Fig. 1. The area of Cabo Frio located in the Brazilian coastal area of Atlantic Ocean. The star symbol, in the bottom left, indicates the position of the ship Antares during the experiment $\left(23^{\circ} 00^{\prime} \mathrm{S}\right.$; $\left.42^{\circ} 08^{\prime} \mathrm{W}\right)$. The plus symbol, in the upper left, indicates the position of the surface station of São Pedro D'Aldeia in the continent $\left(22^{\circ} 48^{\prime} \mathrm{S} ; 42^{\circ} 05^{\prime} \mathrm{W}\right)$. 
measurements were obtained using one pyranometer LIQUOR (LI1000) coupled to a data acquisition system manufactured by Campbell Lab. Inc (Datalogger). The pyranometer was set in the middle of the vessel to minimize the ship motion effects. It provided hourly values of global solar radiation continuously, from July 7 until July 9. The sample rate for solar radiation was $0.1 \mathrm{~Hz}$. No correction was made to compensate the ship motion effect on solar radiation measurements.

\section{Thickness of the atmospheric and oceanic mixed} layer

In this work it was assumed that the vertical extension of the ABL and OBL can be represented by their respective mixed layer thickness. In the case of the atmosphere, the atmospheric mixed layer (AML) height was determined, by visual inspection, as the level from which the vertical gradients of potential temperature and specific humidity increase significantly (Tennekes, 1973; Fitzjarrald \& Garstang, 1981). Similar criterion was applied to sea temperature profiles to estimate the vertical extension of the oceanic mixed layer (OML) (Zilitinkevich et al., 1979). Close to the surface, the fine structure of temperature in both layers was not considered in this analysis because they were affected by the presence of the ship.

Figure 2 exemplifies two typical vertical profiles of potential temperature and specific humidity of the air and the respective profiles of sea temperature measured on July 7 (nighttime) and 9 (daytime). At nighttime of July 7 the potential temperature and specific humidity indicated the presence of an AML with vertical extension of 1000 m (Figs $2 a$ and $2 c$ ). At daytime of July 9, these two profiles indicated the presence of a $500 \mathrm{~m}$ high AML (Figs. $2 \mathrm{~b}$ and $2 \mathrm{~d}$ ). The corresponding sea temperature profiles indicated the presence of an OML with $36 \mathrm{~m}$ at nighttime of July 7 (Fig. 2e) and $55 \mathrm{~m}$ at daytime of July 9 (Fig. $2 f$ ).
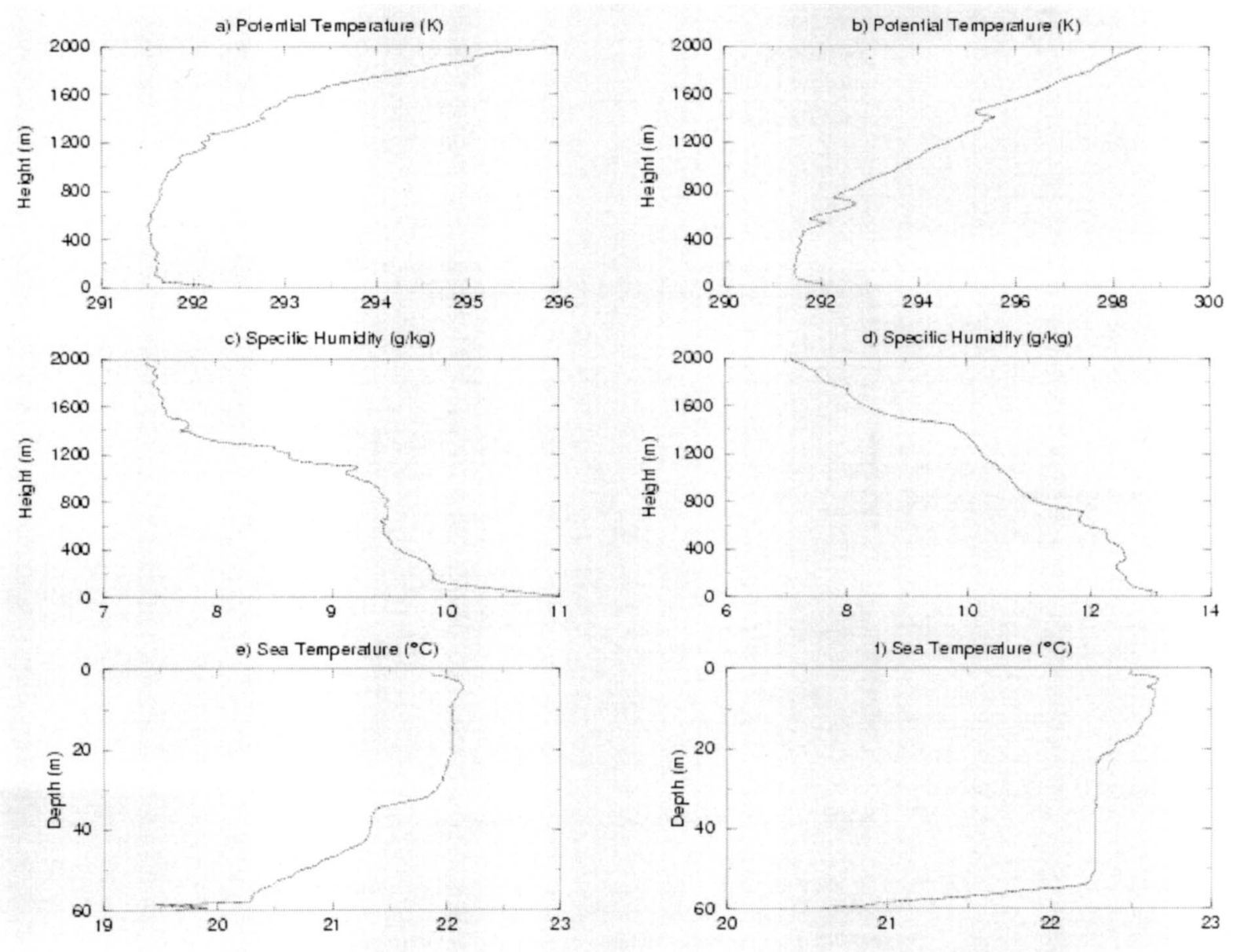

Fig. 2. Profiles of potential temperature observed at (a) at 20:46 Local Time (LT) on July 7 and (b) 12:53 LT on July 9. Profiles of specific humidity observed at (c) 20:46 LT on July 7 and (d) 12:53 LT on July 9. Profiles of sea temperature observed at (e) 20:46 LT on July 7 and (f) 12:53 LT on July 9. 
Despite the subjectivity, the criteria applied here allowed to identify a significant number of AML and OML during the period of observation as indicated in Table 1. It should be emphasized here that the AML was easier to identify when the vertical profiles of specific humidity were included in the analysis.

\section{Discussion}

The synoptic conditions during the experiment indicated a penetration of a frontal system on July 6 (Fig. 3) in the area of Cabo Frio. Measurements of global solar radiation carried out on

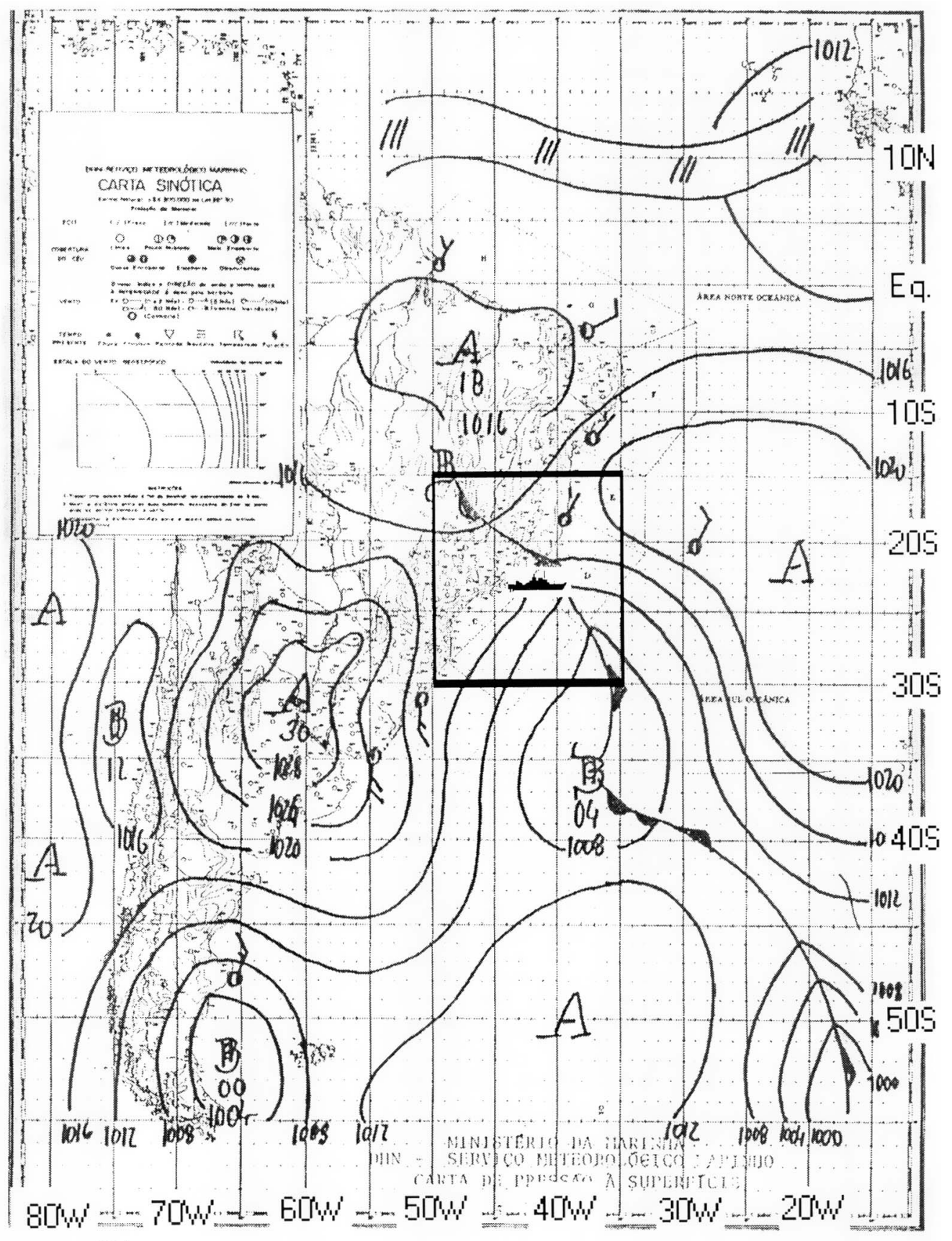

Fig. 3. Synoptic chart at 21:00 LT on July 6, 1992, for the surface level. The ship symbol, in small square in the center, indicates the position of ship Antares during the experiment $23^{\circ} 00^{\prime} \mathrm{S}, 42^{\circ} 08^{\prime} \mathrm{W}$ ). Source "Diretoria de Hidrografia e Navegação", Brazilian Navy. 
board the ship and estimated theoretically for clear sky condition on July 8 (Dourado, 1994), are shown in figure (Fig. 4). The cold front passage reduced the global solar radiation at the surface considerably (Oliveira, 1986), indicating that there is very little solar energy available to alter the thermal state of the ocean in the area of Cabo Frio during the passage of the cold front. Even though, the only available measurements of surface wind during the campaign were carried out over the continent, in São Pedro D'Aldeia, $12 \mathrm{~km}$ far from the ship (Fig. 1), they were in good agreement with few observations made on board of the ship (Fig. 5 and Table 1). This matching indicates that surface wind observed in São Pedro D'Aldeia was representative of the area of Cabo Frio. Thus, the available observations indicate that on July 6 the wind direction shifts from NE (pre-frontal conditions) to SSW (post-frontal condition) (Fig. 5). The direction shift was followed by an increase in wind speed from $5 \mathrm{~m} / \mathrm{s}$ to $10 \mathrm{~m} / \mathrm{s}$.

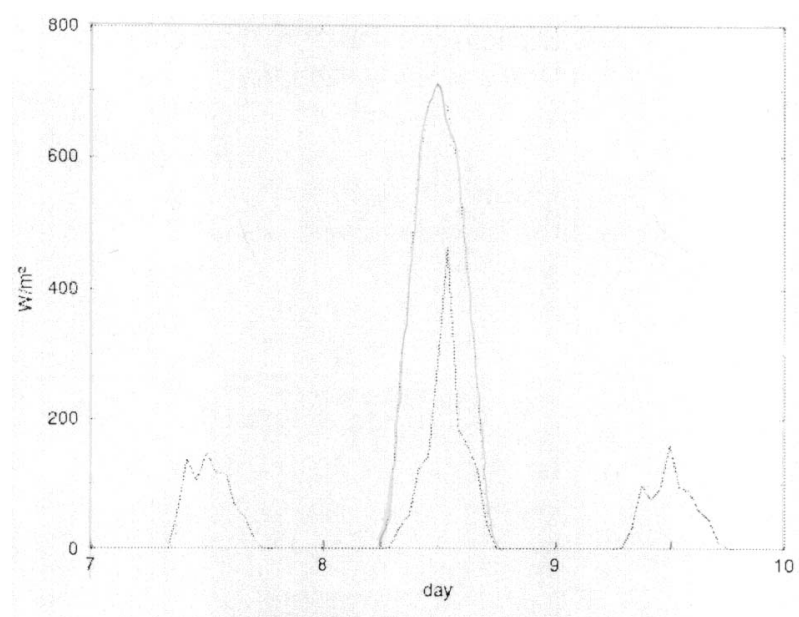

Fig. 4. Time evolution of global solar radiation observed during the experiment on board of Antares. The global solar radiation at the surface, estimated theoretically for clear sky conditions for July 8 , is indicated by dash line.

(a)

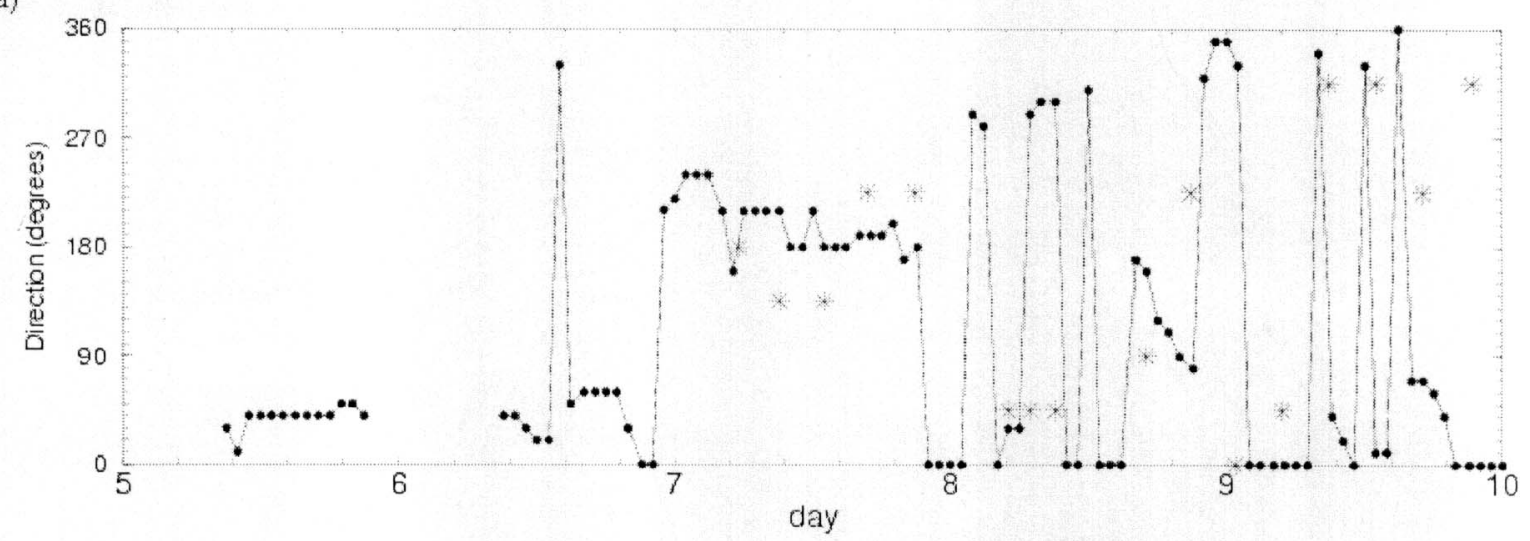

(b)

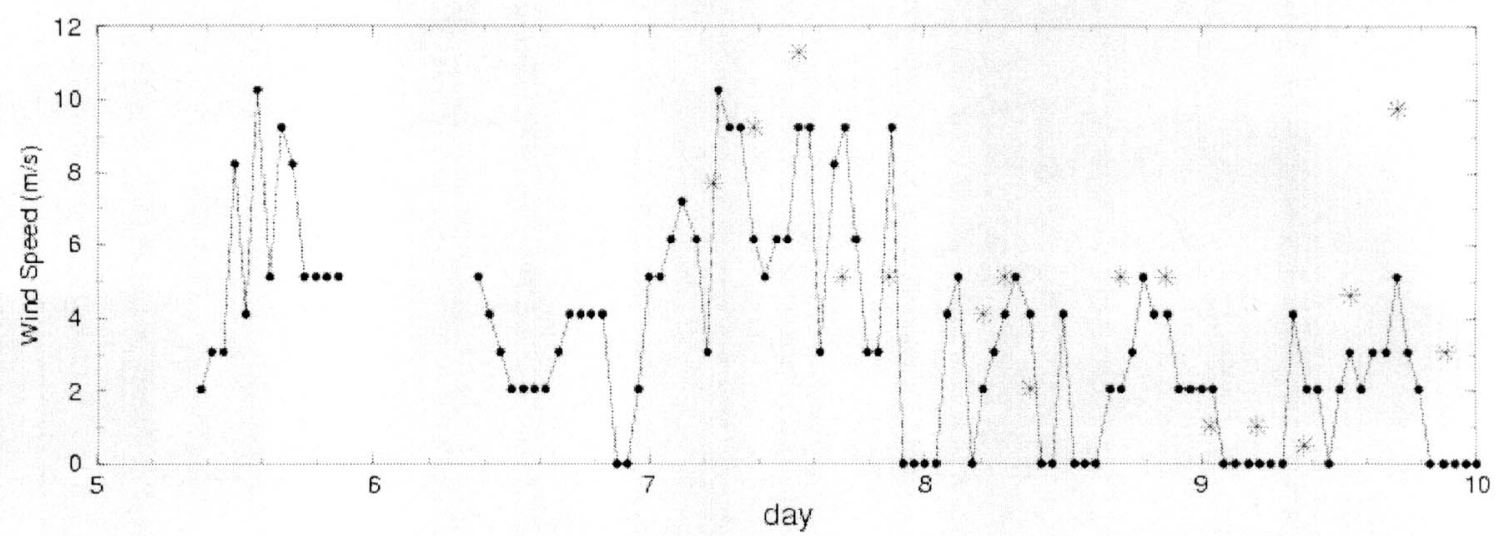

Fig. 5. Time evolution of (a) wind direction and (b) wind speed observed during the experiment at São Pedro D'aldeia. The star symbols indicate the observations carried out on board of Antares. 
Table 1. Description of the atmospheric and oceanic soundings (number, day and local time), vertical extent of AML and $\mathrm{OML}$, wind direction and speed observed on board of Antares during the experiment in Cabo Frio.

\begin{tabular}{|c|c|c|c|c|c|c|}
\hline & Day & Hour (LT) & AML (m) & OML (m) & Wind direction & $\begin{array}{c}\text { Wind speed } \\
\text { (m/s) }\end{array}$ \\
\hline 01 & July 7 & $01: 49$ & & 13 & - & - \\
\hline 02 & July 7 & $05: 36$ & & 19 & S & 7.7 \\
\hline 03 & July 7 & $05: 53$ & 200 & & - & - \\
\hline 04 & July 7 & $09: 05$ & 250 & 19 & SW & 9.3 \\
\hline 05 & July 7 & $13: 02$ & & 21 & SW & 11.3 \\
\hline 06 & July 7 & $16: 52$ & & 34 & SE & 5.1 \\
\hline 07 & July 7 & $20: 46$ & 1000 & 36 & SE & 5.1 \\
\hline 08 & July 8 & $00: 55$ & & 56 & - & calm \\
\hline 09 & July 8 & $05: 00$ & & 59 & NW & 4.1 \\
\hline 10 & July 8 & $06: 53$ & & & NW & 5.1 \\
\hline 11 & July 8 & $09: 00$ & & 43 & NW & 2.1 \\
\hline 12 & July 8 & $13: 03$ & & 37 & - & calm \\
\hline 13 & July 8 & $17: 00$ & & 47 & E & 5.1 \\
\hline 14 & July 8 & $20: 54$ & & 44 & SE & 5.1 \\
\hline 15 & July 9 & $00: 43$ & 250 & 33 & N & 1.0 \\
\hline 16 & July 9 & $04: 46$ & & 58 & NW & 1.0 \\
\hline 17 & July 9 & $08: 57$ & 200 & 53 & NE & 0.5 \\
\hline 18 & July 9 & $12: 53$ & 500 & 55 & NE & 4.6 \\
\hline 19 & July 9 & $16: 59$ & & 48 & SE & 9.8 \\
\hline 20 & July 9 & $21: 20$ & & 52 & NE & 3.1 \\
\hline 21 & July 10 & $00: 49$ & & 47 & NE & 5.1 \\
\hline
\end{tabular}

The radiosonde data indicates a progressive cooling and drying of the atmospheric mixed layer associated to the cold front passage. For instance, on July 7 the virtual potential temperature of the AML decreased from $298 \mathrm{~K}$ to $292 \mathrm{~K}$ (Fig. 6). In the same period the specific humidity in the AML varied from $16 \mathrm{~g} / \mathrm{kg}$ to $10 \mathrm{~g} / \mathrm{kg}$ (Fig. 7), and the AML height varied from $200 \mathrm{~m}$ to $1000 \mathrm{~m}$ (Table 1).
The most robust phenomena observed during the experiment was the increase of OML temperature, from $21.3^{\circ} \mathrm{C}$ to $22.5^{\circ} \mathrm{C}$, followed by deepening of the $\mathrm{OML}$, from $13 \mathrm{~m}$ to $59 \mathrm{~m}$, beginning at midday on July 7 (Fig. 8). The OML growth and increase of temperature occurred during the period when the wind was from SSW (Fig. 5).

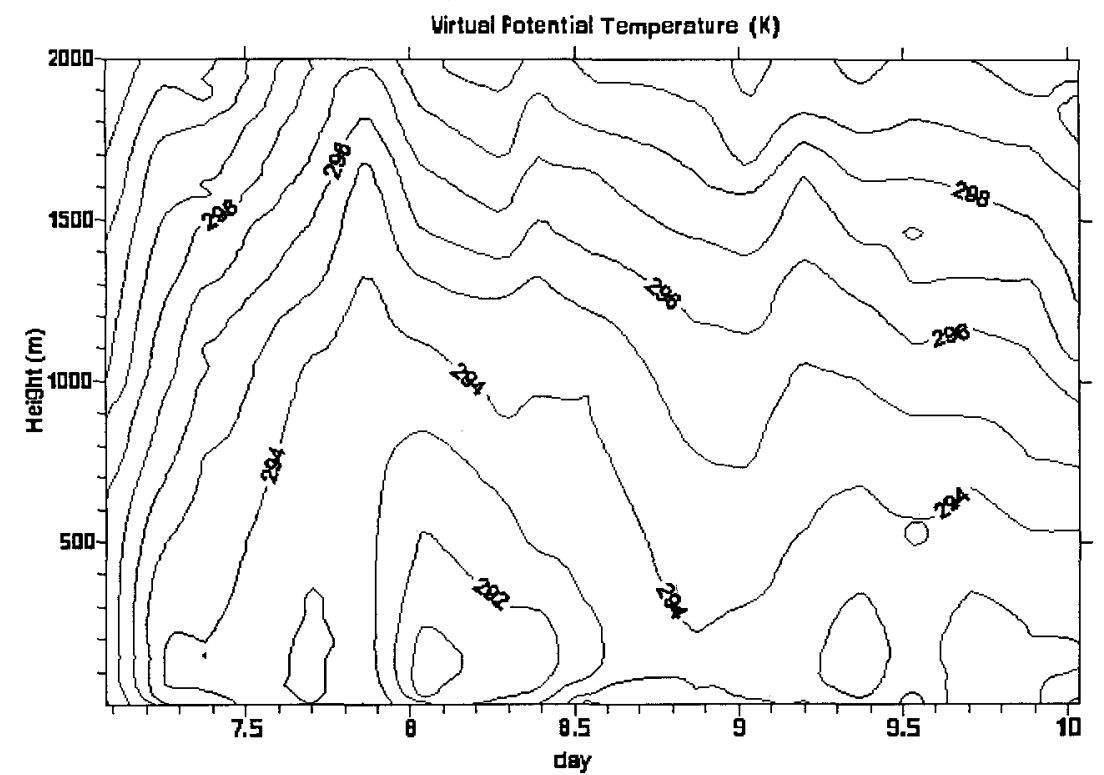

Fig. 6. Time evolution of virtual potential temperature observed in the first $2 \mathrm{~km}$ of the atmosphere during the experiment. 


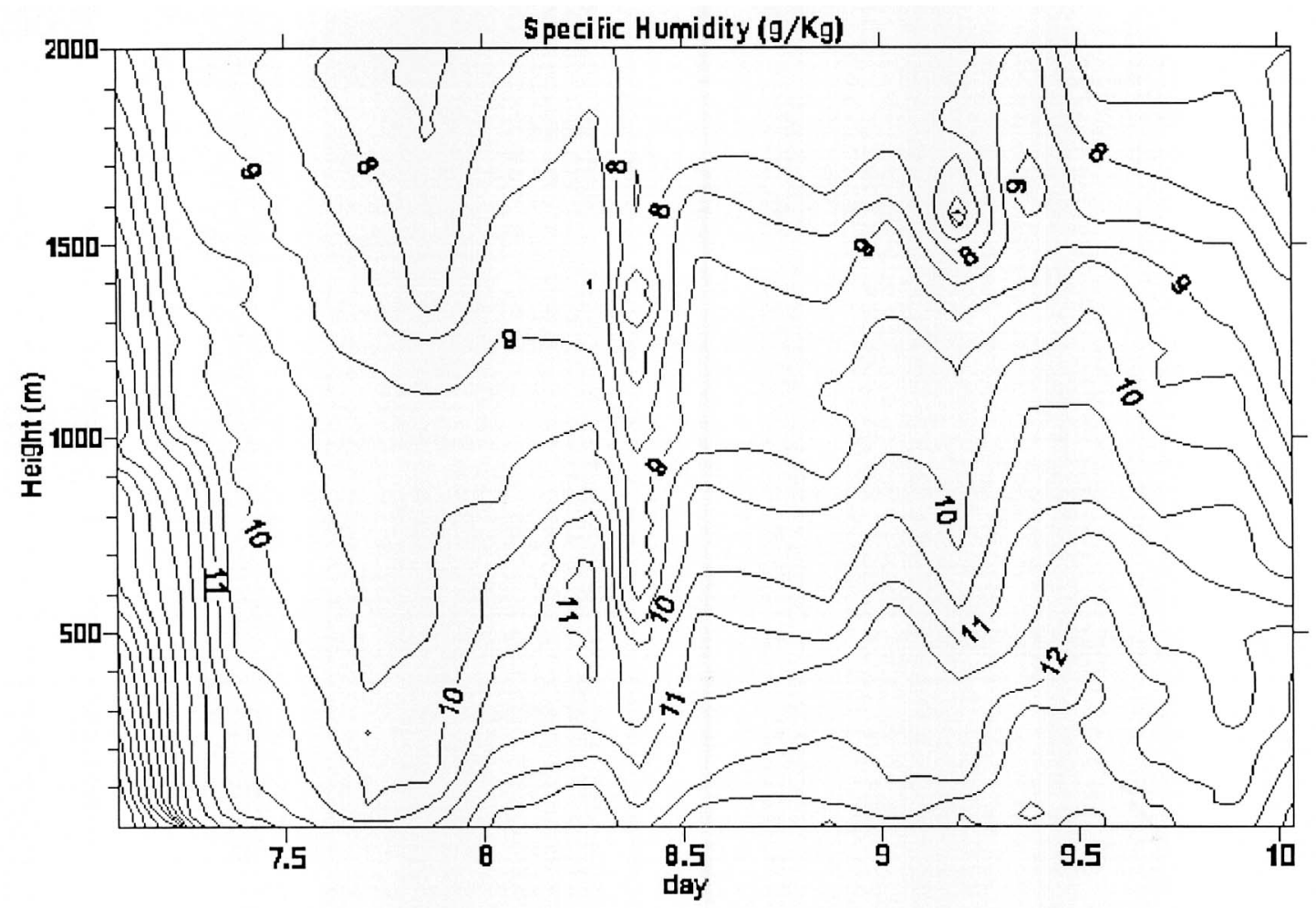

Fig. 7. Time evolution of specific humidity observed in the first $2 \mathrm{~km}$ of the atmosphere during the experiment.

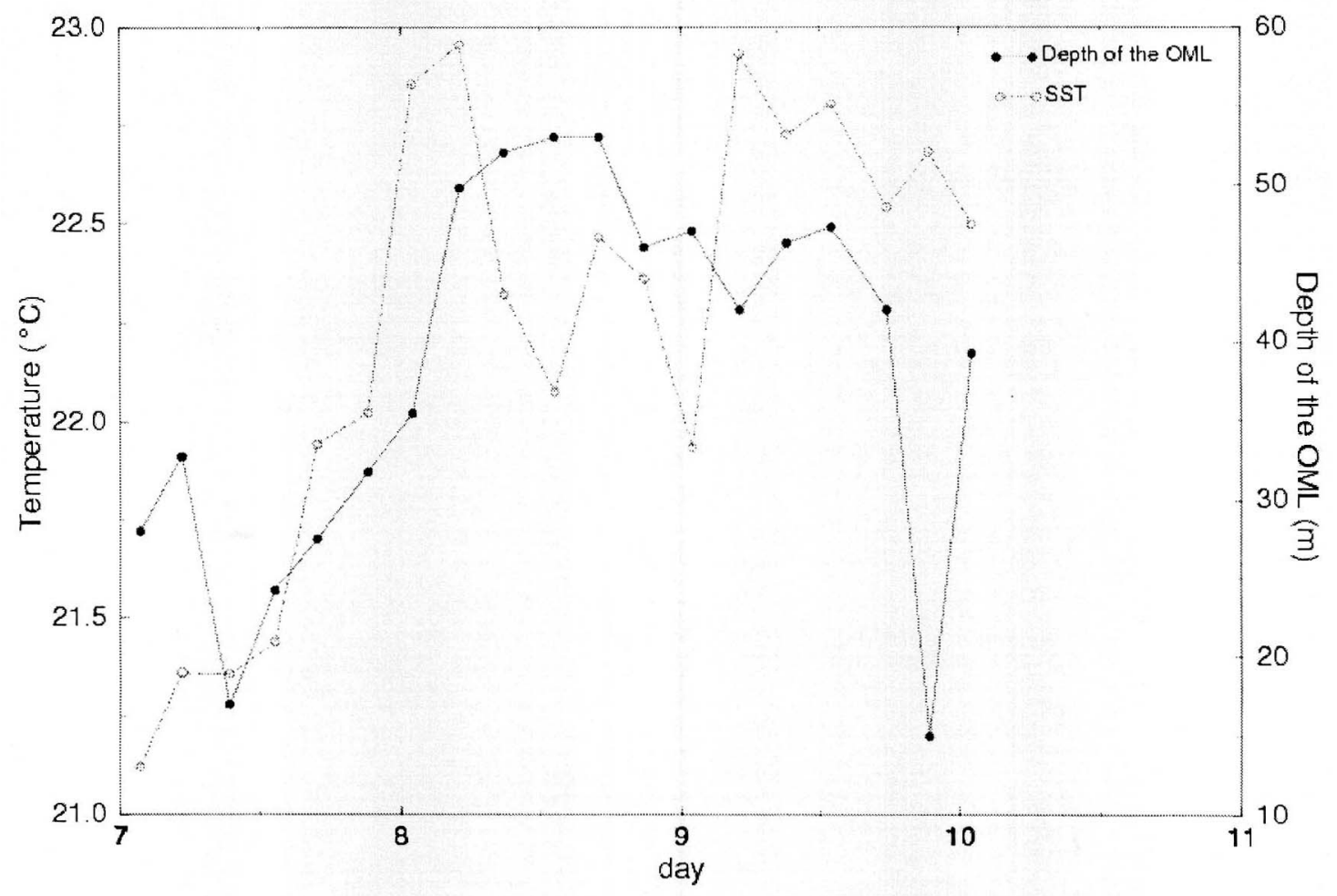

Fig. 8. Time evolution of sea surface temperature (SST) and depth of the OML observed during the experiment. 
The variation in the OML can be explained in terms of the downwelling in Cabo Frio (GonzalesRodrigues, 1992). In general, under undisturbed conditions, the Subtropical South Atlantic Anticyclone generated ENE winds in the PBL over Cabo Frio area. Under this condition, the local coastal superficial waters flow off to the open ocean due to Ekman mechanism and are substituted by colder waters from deeper layers (Fig. 9). This upwelling behavior, observed with large frequency in Cabo Frio, inverts when winds changed to SSW, as observed during the passage of the frontal system described here. In this case, occurs a convergence of warmer water from shallower layers associated to continental Brazil current, producing a downwelling in Cabo Frio (Gonzales-Rodrigues 1992). Therefore, the observed increase of OML temperature can be explained by advection of the waters from the coastal current of Brazil during the downwelling in Cabo Frio. Similarly, the increase in the vertical extension of
OML is consistent with the expected deepening of OML induced by advection of equatorial waters brought by this current. Large values of OML depth can also be explained in terms of an intensification of mechanical mixing induced by the augment of the wind speed as the cold front passed by the area (Fig. 5). Comparatively to other tropical oceanic regions (Johnson et al., 1996), the large variability shown by AML in Cabo Frio seems to be associated to cold fronts penetration during winter and their effect upon the upwelling. One possible cause for high AML, as the $1000 \mathrm{~m}$ AML observed at 20:46 LT on July 7 (Table 1), is the intensification of thermally induced turbulent mixing caused by the heating of the oceanic upper layers $\left(1.2^{\circ} \mathrm{C}\right)$ coupled to the cooling of the adjacent atmospheric air $(6 \mathrm{~K})$ as the cold front air moves in (Fig. 8). Another possibility is the advection of AML generated over the continental areas near by Cabo Frio by the SSW winds (Fig. 3).

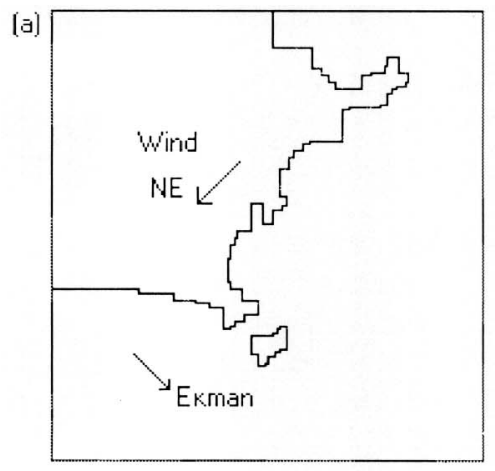

[ibi]

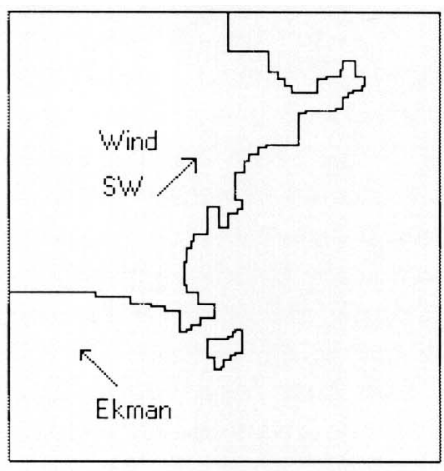

(d)

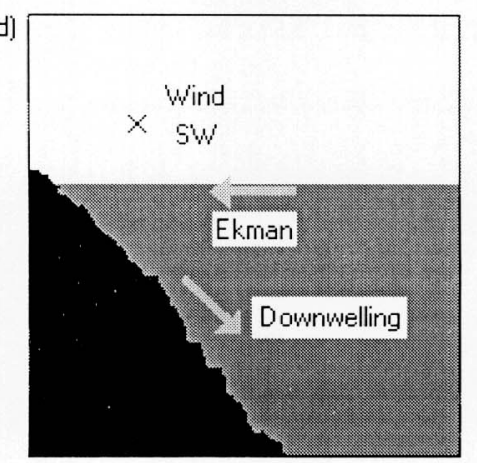

Fig. 9. Schematic description of upwelling and downwelling dynamics for the region Cabo Frio. Drawings (a) and (b) sketch wind and Ekman flow on horizontal planes for upwelling and downwelling, respectively. Drawings (c) and (d) are equivalent to (a) and (b) for vertical planes oriented in the North-South direction. 


\section{Conclusion}

The time evolution of the vertical structure of the atmospheric and oceanic boundary layers observed in the Atlantic Ocean during the passage of a cold front system is presented. These observations were carried out between July 7 and 10, 1992, in the Cabo Frio area characterized by upwelling cold surface waters. They correspond to 19 simultaneous vertical soundings of the atmosphere and ocean, carried on board of the oceanographic ship Antares of the Brazilian Navy, anchored in $23^{\circ} 00^{\prime} \mathrm{S}$ and $42^{\circ} 08^{\prime} \mathrm{W}$. During the cold front passage in the region of Cabo Frio the $\mathrm{ABL}$ and $\mathrm{OBL}$ showed significant variations. The $\mathrm{ABL}$, represented by the AML, cooled about $6 \mathrm{~K}$, dried about $6 \mathrm{~g} / \mathrm{kg}$ and increased its vertical extension from $200 \mathrm{~m}$ to $1000 \mathrm{~m}$. The OBL, represented also by its $\mathrm{OML}$ portion, heated about $1.2^{\circ} \mathrm{C}$ and deepened $46 \mathrm{~m}$. As result of the cold front passage, the wind shift from NE to. SSW and the upwelling in Cabo Frio is substituted by downwelling regime, inducing a gradual heating and deepening of the OML. In this case, the increase in the OML depth is due to the fact that the downwelling mechanism induces superficial convergence of warmer waters originated from areas that are characterized by large OML depths. Large values of OML depth can also be explained in terms of an intensification of mechanical mixing induced by the augment of wind speed as the cold front passed by the area. The large variability of the vertical extension of AML can also be linked to the passage of cold front in two ways. The first one is by the intensification of thermally induced turbulent mixing by the warming of the upper layers of the ocean coupled to the cooling of lower later atmosphere. The second one is by advection of continental PBL by the SSW wind after the passage of cold front. The explanations for the ABL variations observed in Cabo Frio are consistent with the observations carried out by Friehe et al. (1991) during the FASINEX. However, they do not totally agree with observations carried out by Austin \& Lentz (1999) at larger latitudes. Their results show that for the coast of North Carolina, the temperature of the ABL undergoes adjustment when warm air blows over cold water but not when cold air blows over warm water. Thus, the hypothesis used to explain the behavior of the atmospheric and oceanic boundary layers in Cabo Frio, during the cold front passage, will have to be further investigated by either carrying out another more extensive observational campaign or by modelling numerically the interaction between these two boundary layers. In both approaches the observations described in this work can be used as reference.

\section{Acknowledgments}

We acknowledge support provided by the Brazilian Research Agency CNPq. We thank to the "Instituto de Estudos do Mar Almirante Paulo Moreira" and the Brazilian Navy for making the data set available to this research.

\section{References}

Albrecht, B. A.; Bretherton, C. S. \& Johnson, D. W. 1994. An overview of the atlantic stratocumulus transition experiment --- ASTEX. In: International Conference On Air - Sea Interaction And On Meteorology And Oceanography Of The Coastal Zone, 2. Lisboa, 1994. Proceedings. Boston, American Meteorological Society, p. 34-35.

Augstein, E.; Riehl, H.; Ostapoff, F. \& Wagner, V. 1973. Mass and energy transports in an undisturbed Atlantic trade wind flow. Mon. Weath. Rev. 101(2):101-111.

Austin, J. A. 1999. The role of alongshore wind stress in the heat budget of North Caroline inner shelf. $\mathbf{J}$. geophys. Res., 104(C8): 18,187-18,203.

Austin, J. A. \& Lentz, S. J. 1999. The relationship between synoptic weather systems and meteorological forcing on the North Carolina inner shelf. J. Geophys. Res. 104(C8):18,15918,185 .

Betts, A. K. \& Albrecht, B. A. 1987. Conserved variable analysis of the convective boundary layer thermodynamic structure over the tropical Oceans. J. atmos. Sci. 44(1):83-99.

Dourado, M. S. 1994. Estudo da camada limite planetária atmosférica marítima. M.Sc. Dissertation. São José dos Campos, Instituto Nacional de Pesquisas Espaciais. 100p.

Dupuis, H.; Frangi, J. P. \& Weill, A. 1993. Comparison of wave breaking statistics using underwater noise and sea surface photographic analysis conducted under moderate wind speed during the SOFIA/ASTEX experiment. Annls Geophys., 11(10):960-969.

Firestone, J. K. \& Albrecht, B. A. 1986. The structure of the atmospheric boundary layer in the central equatorial pacific during January and February of FGGE. Mon. Weath. Rev. 114(11):2219-2231. 
Fitzjarrald, D. R. \& Garstang, M. 1981. Vertical structure of the tropical boundary layer. Mon. Weath. Rev. 109(7):1512-1526.

Friehe, C. A.; Shaw, W. J.; Rogers, D. P.; Davidson, K. L.; Large, W. G.; Stage, S. A.; Crescenti, G. H.; Khalsa, S. J. S.; Greenhut, G. K. \& Li, F. 1991. Air-sea fluxes and surface layer turbulence around a sea surface temperature front. J. geophys. Res. 96(C5):8593-8609.

Geernaert, G. L. 1990. Bulk parameterization for the wind stress and heat fluxes. In: Geernaert, G. L. \& Plant, W. P. eds. Surface waves and fluxes. Boston, Dordrecht, 1:91-172.

Gonzales-Rodrigues, E; Valentin, J. L.; André, D. L. \& Jacob, S. A. 1992. Upwelling and Downwelling at Cabo Frio (Brazil): Comparison of biomass and primary production responses. J. Plankt. Res., 14(2):289-306.

Holland, J. Z. \& Rasmusson, B. M. 1973. Measurements of the atmospheric mass, energy, and momentum budgets over a 500 kilometer square of tropical ocean. Mon. Weath. Rev., 101(1):44-55.

Houze, R. A. 1977. Structure and dynamics of a tropical squall line system observed during GATE. Mon. Weath. Rev. 105(12):1540-1567.

Johnson, P. E.; Cieselski, P. E. \& Hart, K. E. 1996. Tropical inversions near the $0^{\circ}$ level. J. atmos. Sci., 96:1838-1855.

Kloesel, K. A. \& Albrecht, B. A. 1989. Low - Level inversions over the tropical pacificthermodynamic structure of the boundary layer and the above-Inversion moisture structure. Mon. Weath. Rev., 117(1):87-101.

LeMone, M. A. \& Pennell, W. T. 1976. The relationship of trade wind cumulus distribution to subcloud layer fluxes and structure. Mon. Weath. Rev., 104(5):524-539.

Nicholls, S. \& LeMone, M. A. 1980. The fair weather boundary layer in GATE: The Relationship of subcloud fluxes and structure to the distribution and enhancement of cumulus clouds. J. atmos. Sci., 37(9):2051-2067.
Oliveira, A. S. 1986. Interações entre sistemas frontais na América do Sul e a convecção da Amazônia. INPE-4008-TDL/239. São José dos Campos, Instituto Nacional de Pesquisas Espaciais. 115 p.

Reed, R. J. \& Recker, E. E. 1971. Structure and properties of synoptic - scale wave disturbances in the equatorial western pacific. J. atmos. Sci., 28(7):1117-1133.

Stech, J. L. \& Lorenzzetti, J. A. 1992. The response of the South Brazil Bight to the passage of wintertime cold fronts. J. Geophys. Res., 97(6):9507-9520.

Taylor, P. K. 1989. World ocean circulation experiment: surface flux determinations: A strategy for in situ measurements. WMO/TD 304.

Torres Jr., A. R. 1995. Resposta da ressurgência costeira de Cabo Frio forçantes locais. M.Sc. Dissertation. Rio de Janeiro, UFRJ-COPPE. $143 \mathrm{p}$.

Tennekes, H. 1973. A model for the dynamics of the inversion above a convection boundary layer. J. atmos. Sci., 30(4):558-567.

Webster, P. J. \& Lukas, R. 1992. TOGA COARE: The coupled ocean - atmosphere response experiment. Bull. Am. met. Soc., 73(9):13771416 .

Yanai, M.; Esbensen, S. \& Chu, J. H. 1973 Determination of bulk properties of tropical cloud clusters from large-scale heat and moisture budgets. J. atmos. Sci., 30(4):611-627.

Zilitinkevich, S. S.; Chalikov, D. V. \& Resnyansky, Y. D. 1979. Modelling the oceanic upper layer. Oceanologica Acta, 2(2):219-240.

Zipser, E. J. 1977. Mesoscale and convective-scale downdrafts as distinct components of squall-line circulations. Mon. Weath. Rev., 105(12):15681589.

(Manuscript received 02 August 2001; revised 12 April 2002; accepted 27 June 2002) 